\title{
Vertebroplasty reduces progressive 'creep' deformity of fractured vertebrae
}

\author{
J Luo+, P Pollintine, DJ Annesley-Williams*, P Dolan, MA Adams. \\ Centre for Comparative and Clinical Anatomy, University of Bristol, Bristol, U.K. \\ + University of Roehampton \\ *Queen's Medical Centre, Nottingham, U.K.
}

\section{Corresponding author:}

Professor Michael A. Adams BSc PhD,

Centre for Comparative and Clinical Anatomy,

University of Bristol,

Southwell Street,

Bristol BS2 8EJ, U.K.

M.A.Adams@bris.ac.uk

Tel. +441179288363

Keywords: vertebra; bone; creep; vertebroplasty; deformity

Word count (Intro-Acknowledgements): $\mathbf{3 , 4 4 0}$ 


\begin{abstract}
Elderly vertebrae frequently develop an "anterior wedge" deformity as a result of fracture and creep mechanisms. Injecting cement into a damaged vertebral body (vertebroplasty) is known to help restore its shape and stiffness. We now hypothesise that vertebroplasty is also effective in reducing subsequent creep deformations. Twenty-eight spine specimens, comprising three complete vertebrae and the intervening discs, were obtained from cadavers aged 67-92 yrs. Each specimen was subjected to increasingly-severe compressive loading until one of its vertebrae was fractured, and the damaged vertebral body was then treated by vertebroplasty. Before and after fracture, and again after vertebroplasty, each specimen was subjected to a static compressive force of $1 \mathrm{kN}$ for $1 \mathrm{hr}$ while elastic and creep deformations were measured in the anterior, middle and posterior regions of each adjacent vertebral body cortex, using a 2D MacReflex optical tracking system. After fracture, creep in the anterior and central regions of the vertebral body cortex increased from an average 4,513 and 885 microstrains, respectively, to 54,107 and 34,378 microstrains (both increases: $\mathrm{P}<0.001$ ). Elastic strains increased by a comparable amount. Vertebroplasty reduced creep in the anterior and central cortex by $61 \%(\mathrm{P}=0.006)$ and $66 \%(\mathrm{P}=0.017)$ respectively. Elastic strains were reduced by less than half this amount. Results suggest that the beneficial effects of vertebroplasty on the vertebral body continue long after the post-operative radiographs. Injected cement not only helps to restore vertebral shape and elastic properties, but also reduces subsequent creep deformation of the damaged vertebra.
\end{abstract}

\title{
Introduction
}

Osteoporotic vertebral compressive fracture is a large and growing problem in ageing societies (Burger et al., 1997). Typically, one or more thoracolumbar vertebrae sustains an anterior wedge deformity as the anterior region of the vertebral body collapses (Ismail et al., 1999). In severe cases, the entire spine develops a "senile kyphosis" which can be painful and disabling (Francis et al., 2008; Miyakoshi et al., 2015).

The underlying cause of this condition is loss of bone density and strength, as a result of hormonal changes (and reduced physical activity) in elderly people (Ettinger et al., 1998; Ismail et al., 2000). Vertebrae are particularly affected because they have a high proportion of trabecular to cortical bone, and trabecular bone provides a large surface-to-volume ratio for the bone resorbing cells (osteoclasts) to act upon (Tower et al., 2015). It is preferable to refer to vertebral "deformity" rather than fracture, because radiographs often reveal no clear fracture plane, and the patient often recalls no traumatic incident (Jiang et al., 2010). Also, recent experiments have shown that cadaveric vertebrae can be deformed substantially by a slow quasi-continuous "creep" mechanism which does not appear to be 
fully reversible, at least in-vitro (Pollintine et al., 2009) (Yamamoto et al., 2006). Bone creep is an old concept (Currey, 1965; Zilch et al., 1980) although its mechanism remains poorly understood (Pollintine et al., 2009). It increases markedly when bone mineral density (BMD) is low (Luo et al., 2012) (Pollintine et al., 2009), as it often is in the anterior region of the vertebral body (Adams et al., 2006) (Briggs et al., 2012). Vertebral body creep is greatly increased if the vertebra has previously been loaded beyond its elastic limit (Luo et al., 2012) as shown in Figure 1.

Injecting cement into an affected vertebra, using the techniques of vertebroplasty or kyphoplasty (Garfin et al., 2001), increases vertebral compressive stiffness and strength (Belkoff et al., 1999)(Luo et al., 2007). It can help to reverse the anterior "wedge" deformity also (Landham et al., 2015a). Uncontrolled clinical trials suggest that these "cement augmentation" techniques are beneficial to patients, but this has been questioned by two controlled studies (Buchbinder et al., 2009; Kallmes et al., 2009) which have themselves been criticised on methodological grounds, so that clinical efficacy remains controversial. Nevertheless, there is still widespread interest in developing and further evaluating these techniques.

In order to clarify the mechanical benefits of vertebroplasty, we test the hypothesis that cement augmentation reduces creep deformations more than elastic deformations in damaged human vertebrae. If the hypothesis is supported, it will suggest that the full benefits of cement augmentation will be underestimated by radiographs taken immediately after the procedure, because the injected cement would continue to oppose progressive vertebral deformity during the following days or months, until full bone healing has taken place.

\section{Materials and Methods}

Cadaveric material Fourteen thoracolumbar spines (10 male, 4 female) were obtained from cadavers aged 67-92 years (mean 80 years) that were donated for medical research. Spines were stored in sealed bags at $-20^{\circ} \mathrm{C}$ until required for testing. Subsequently, each spine was thawed and dissected into a pair of "motion segments", comprising three vertebrae with the intervening intervertebral discs and ligaments intact (Figure 2). A total of 28 motion segments were used. Spinal levels ranged between T8-T10 and L2-L4. Choice of level was determined by the need to avoid large osteophytes (which interfere with disc stress measurements) and the need to maximize use of scarce human tissue. Before testing, the bone mineral content of each vertebra was assessed using dual energy Xray absorptiometry (Luo et al., 2007). After testing, each vertebral body was dissected free from its neural arch and adjacent discs, and its volume was measured by water displacement for the calculation of volumetric bone mineral density (BMD). Each intervertebral disc was sectioned in the 
transverse plane and graded for disc degeneration, using points 1 (non-degenerated) to 4 (severely degenerated) as described previously (Adams et al., 1986).

Overview of experiments The sequence of tests on each of the 28 specimens is summarised in Figure 3. During an initial creep test ( $1.0 \mathrm{kN}$ compression, 1 hour, $0^{\circ}$ flexion), an optical MacReflex system measured elastic and creep strains in all three vertebral bodies. Each specimen was then positioned in flexion, and compressed until one of its vertebrae fractured. The creep test and strain measurements were repeated immediately, as before. The fractured vertebra was then strengthened by injecting cement into it ("vertebroplasty"). Each specimen was then creep-loaded for a third period of 1 hour $\left(0^{\circ}\right.$ flexion $)$, and strain measurements were repeated. The distribution of compressive "stress" within both intervertebral discs of each specimen (stress profilometry) was measured four times: after each of the three creep tests and after vertebroplasty. On each occasion, stress profiles were recorded from each disc in a flexed and then an extended posture. In this way, the experiments studied the influence of a) vertebral fracture and b) vertebroplasty on vertebral body stresses and strains.

Mechanical loading Each specimen was secured in 2 cups of dental plaster and loaded on a computer-controlled, hydraulic materials testing machine (Dartec-Zwick-Roell, Leominster, U.K.) fitted with a $10 \mathrm{kN}$ load cell. As described previously (Luo et al., 2007) the apparatus (Figure 2) used two low-friction rollers to apply compressive loading to a specimen positioned in a neutral posture (rollers of equal height), flexed posture (posterior roller lower) or extended posture (anterior roller lower). A preliminary short period of compressive loading (300 $\mathrm{N}$ for 15 minutes) was applied to ensure that disc hydration was brought within the physiological range at the start of the experiment (McMillan et al., 1996).

Stress profilometry This well-established (McNally and Adams, 1992) and validated (Chu et al., 2008) technique was used to quantify the vertically-acting compressive "stress" applied by the loaded intervertebral discs to their adjacent vertebral bodies. A miniature pressure transducer (Gaeltec, Dunvegan, U.K.), side-mounted in a $1.3 \mathrm{~mm}$ diameter needle, was used to measure the distribution of compressive "stress" along the mid-sagittal diameter of the intervertebral disc (Figure 4). During stress profilometry, each motion segment was subjected to a compressive force of $1.0 \mathrm{kN}$ (20 specimens), $0.75 \mathrm{kN}$ ( 5 specimens) or $0.5 \mathrm{kN}$ ( 3 specimens), depending on specimen size and BMD (Adams et al., 1996; Luo et al., 2007). Stress profiles were recorded from each disc with the specimen positioned in $2^{\circ}$ of extension, to simulate the erect standing posture (Adams and Hutton, 1980), and also in $4^{\circ}-6^{\circ}$ of flexion (depending on specimen mobility) to simulate moderately flexed postures typical of manual work (Dolan et al., 1994). For each specimen, the same angles were used throughout the stages of the experiment. Stress profiles (Figure 4) indicate the average intradiscal 
pressure (IDP) in the nucleus of the disc, and the size of stress concentrations in the anterior $\left(\mathrm{SP}_{\mathrm{A}}\right)$ and posterior $\left(\mathrm{SP}_{\mathrm{P}}\right)$ annulus. Horizontally-acting stresses (shown in blue in Figure 4) were also measured by rotating the transducer needle about its long axis. Obtaining both horizontal and vertical stress profiles (in separate tests) enabled the hydrostatic (nucleus) region to be defined, but only the vertically-acting stresses were used to calculate stress concentrations.

Creep tests Each specimen was positioned in the neutral posture $\left(0^{\circ}\right.$ of flexion $)$ and compressed at $200 \mathrm{~N} / \mathrm{s}$ up to a maximum compressive load of $1.0 \mathrm{kN}$. This force was maintained for one hour. Specimens were then allowed to recover for a further 30 min under a nominal load of $3 \mathrm{~N}$.

Strain measurements Strains in the vertebral bodies were recorded using a MacReflex 2-D optical movement analysis system (Pollintine et al., 2009). As used in the present experiment, this system can track six reflective markers attached to each vertebral body (Figure 2) with in-plane errors of less than $10 \mu \mathrm{m}$ (Green et al., 1994). Analysis of this data revealed changes in the vertical separation of pairs of markers, and hence strains in the anterior, middle and posterior regions of each vertebral body cortex (Luo et al., 2012). MacReflex data was recorded at $50 \mathrm{~Hz}$ during load application and at $1 \mathrm{~Hz}$ during creep. Strain mechanisms are complex in these vertebrae, especially after they are damaged, but for simplicity we define "elastic deformation" as all deformation recorded during load application (5 s) and during the following $2 \mathrm{~s}$ (Luo et al. 2012), and "creep deformation" as the continuing deformation during the following 60 minutes of static loading.

Vertebral fracture Each specimen was positioned in flexion ( $4^{\circ}$ to $10^{\circ}$ depending on flexibility) and compressed to failure at $3 \mathrm{~mm} / \mathrm{s}$ in order to simulate typical forward bending and lifting movements (Dolan et al., 1994), which are known to be common in life (Rohlmann et al., 2014). A loaddeformation graph was plotted in real time to allow the load to be removed at the first sign of damage, which was indicated by a reduction in gradient (stiffness). The compressive force applied at this point was recorded as the yield strength. This value was decided by an experienced engineer (JL) who sometimes used additional information (such as audible signs of failure, or evidence of slipping, or a right-shift in a subsequent graph) as well as the force-deformation graph itself. Radiography Each motion segment was radiographed in the sagittal plane before and after fracture. Radiographs revealed which vertebra was damaged, and how much gross vertebral wedging deformity (in degrees) was caused.

Vertebroplasty Vertebroplasty was then performed on the fractured vertebra using polymethylmethacrylate (PMMA) cement (Simplex ${ }^{\circledR}$, Stryker Instruments, Howmedica International, Limerick, Ireland) or a resin (Cortoss ${ }^{\circledR}$, Orthovita, Malvern, PA, USA). One of each pair of specimens received PMMA, the other received resin, with the upper specimen being 
alternatively assigned to PMMA or resin to avoid bias. As described previously (Luo et al., 2007), a bilateral transpedicular route was used to inject a total volume of $3.5 \mathrm{ml}$ at spinal levels T7 - T12, and $4 \mathrm{ml}$ at spinal level L1 -L5. This volume largely restores normal stress distributions to fractured and adjacent vertebral bodies (Luo et al., 2009). After injection, both needles were removed from the vertebra and the cement or resin was left to set for 1 hour.

Statistical analysis Specimen details in the two groups were compared using matched-pair t-tests. All measurements repeated before and after each intervention were compared using repeated measures ANOVA, with cement type as a between-subject factor. Where a significant main effect was found, post-hoc tests (pairwise comparison with Bonferroni correction) were used to identify where differences arose. Significance was accepted at $\mathrm{P}<0.05$. SPSS $17.0^{\circledR}$ was used for statistical analysis.

\section{Results}

Specimen characteristics did not vary significantly between the two specimen groups, and choice of PMMA or Cortoss had no significant influence on any of the measured variables, as reported previously (Luo et al. 2007). Therefore data from all 28 specimens were pooled for subsequent analysis. Vertebroplasty was successfully completed in all specimens, with leakage (of PMMA cement) being observed in only one specimen.

Vertebral fracture Radiographs showed that fracture occurred in the upper (4 specimens), middle (11) and lower (14) vertebral body. In one specimen, both the middle and lower vertebrae were damaged. Endplate damage was evident in all specimens, adjacent to an intervertebral disc, and this was combined with anterior cortex damage in $21 / 28$ specimens. Fracture created in these (and previous) experiments involves a loss of vertebral body height of approximately $1 \mathrm{~mm}$, and an anterior wedging angle of approximately $1^{\circ}$ (Luo et al. 2010). Compressive yield strength averaged $2.7 \mathrm{kN}$ (range 1.3 $5.5 \mathrm{kN}$ ). Volumetric BMD of the damaged vertebrae ranged from 0.075 to 0.298 (mean 0.169$) \mathrm{g} / \mathrm{mm}^{3}$. The radiographic appearance of typical fractures obtained using these techniques has been reported previously (Jiang et al., 2010).

Stress profilometry Stress profilometry was not completed in 6 intervertebral discs (from 3 specimens) due to damage to the pressure transducer. Fracture and vertebroplasty caused major changes in stress profiles. Essentially, fracture reduced IDP, especially in extended (erect) posture, as load-bearing was transferred from nucleus to the posterior annulus (Table 1), and also from annulus to neural arch as shown previously (Luo et al., 2007). Vertebroplasty partially (but not entirely) reversed the effects of fracture. The final creep test (following vertebroplasty) had little effect on the stress profiles. 
Creep tests and vertebral body strains Loss of reflective markers during the testing period (usually following vertebral damage) sometimes prevented a complete set of strain measurements being obtained from each region of each vertebra. As shown in Table 2, strain data at different stages of the experiment could be compared between up to 29 vertebrae that were adjacent to a damaged endplate. Both elastic and creep strains increased markedly after vertebral fracture (Figure 5). After fracture, creep strain in the anterior vertebral body cortex increased from 4,513 (STD 4,766) to 54,107 (STD $54,845)$ micro-strain $(\mathrm{P}<0.001)$, and creep in the central vertebral body cortex increased from 885 (STD 5,170) to 34,378 (STD 40,762) micro-strain $(\mathrm{P}<0.001)$. Vertebroplasty reduced elastic deformations by $21 \%(\mathrm{P}=0.917)$ and $25 \%(\mathrm{P}=0.133)$ in the anterior and central vertebral body, respectively (Figure 5a). Corresponding reductions in creep strains following vertebroplasty were considerably greater and highly significant: $61 \%$ anteriorly $(\mathrm{P}=0.006)$ and $66 \%$ centrally $(\mathrm{P}=0.017)$ (Figure 5b).

\section{Discussion}

Summary of findings Vertebral fracture substantially transferred compressive load-bearing from nucleus to annulus, and this effect was largely reversed by vertebroplasty (regardless of cement or resin type). Fracture caused elastic and creep strains in the anterior and central vertebral body cortex to increase greatly, and by a comparable amount. Subsequently, vertebroplasty reduced creep strains in the vertebral body cortex more than it reduced elastic strains: reductions in creep were $61 \%$ and $66 \%$ in the anterior and central regions, respectively.

Strengths and limitations of the study The use of three-vertebra specimens ensured that vertebral body compressive damage occurred naturally at a disc-bone interface, and so was not an artefact of the apparatus or dental plaster. Compressing the specimens while positioned in a flexed posture simulated typical physical activities in life (Dolan et al., 1994; Rohlmann et al., 2014) and the fractures created involved typical anterior wedging of the vertebral body. The "stress profilometry" technique has been extensively validated (Chu et al., 2008)(McNally et al., 1992; Pollintine et al., 2004a) and shown to give reasonably accurate measures of the distribution of compressive loading on the vertebral body and neural arch. Specimens used in this study were from elderly humans, which ensured that the results are relevant to the population in which most osteoporotic vertebral deformities occur. Death, and freeze-thawing cycles, have only a small influence on the elastic and creep properties of the human spine (Adams, 1995; Dhillon et al., 2001), although disc creep appears to be affected in young animal spines (Bass et al., 1997). 
Limitations of the study include the fact that vertebral body creep does not fully recover in-vitro, not even after two hours (Pollintine et al. 2009), so it is not possible to state that differences in creep strains between repeated tests are entirely attributable to the intervention (fracture, or vertebroplasty). Nevertheless, the fact that strains increased after the first intervention, and then decreased after the second, in both cases by large amounts, indicates that the interventions were exerting a large influence on measured strains. Other limitations include the volumetric BMD measurements which could possibly be overestimated if fracture created voids within the vertebral body, and uncertainty regarding the precise mechanisms responsible for the measured "elastic" and "creep" strains.

Relationship to other studies The manner in which the disc "stress profiles" were affected by vertebral fracture and by cement augmentation (Table 1), is entirely consistent with our previous work, which also showed that the effects depended little on cement/resin type (Luo et al., 2007) or volume (Luo et al., 2009) or on whether the vertebroplasty or kyphoplasty technique was employed (Luo et al., 2010; Landham et al., 2015). This agreement suggests that the present results may be equally applicable, at least qualitatively, to either form of cement augmentation.

Creep deformation of whole human vertebrae was first studied by Pollintine et al. (Pollintine et al., 2009) who showed that the effect is greatest in the anterior vertebral cortex and least in the posterior cortex, as illustrated in Figure 5b. A marked increase in vertebral body creep following damage has also been reported previously, and the increase shown to be approximately proportional to the amount of vertebral damage, as measured by specimen height loss (Luo et al., 2012). What is novel about the present study is the demonstration that creep deformation in a damaged vertebra can be greatly slowed by injecting just $3.5-4 \mathrm{ml}$ of cement or resin into it.

Explanation of results Vertebral fracture damages the endplate, allowing it to bulge more into the vertebral body under load (Brinckmann et al., 1983). This decompresses the adjacent disc nucleus (Dolan et al., 2013) and transfers compressive load-bearing on to the annulus fibrosus (Stefanakis et al., 2014) and neural arch (Pollintine et al., 2004b; Landham et al., 2015a). Subsequent loading can then be concentrated on to the anterior vertebral body cortex to such an extent that it causes anterior 'wedge' deformity (Landham et al. 2015b). Vertebroplasty partially reverses these essentially elastic changes (Landham et al., 2015) by reducing vertical bulging of the damaged endplate (Hulme et al., 2009). The larger effect of the cement on creep is harder to explain, because the mechanisms of whole-bone creep are poorly understood. Creep strains in the present experiment were measured in the cortex, but probably reflect deformations of both cortical and trabecular bone, which have similar yield strains (Bayraktar et al., 2004). At a microscopic level, creep could conceivably be caused by: dislocations in the lattice structure of hydroxyapatite crystals (Rimnac et al., 1993); or gliding 
between wet crystals of hydroxyapatite (Eberhardsteiner et al., 2014); or slipping between hydroxyapatite crystals and collagen, with accumulation of plastic deformation in the latter (Singhal et al., 2014); or slipping at the cement line; or by the propagation of microcracks within or between osteons (Zioupos et al., 2008; SerefFerlengez et al., 2014). At a macroscopic or structural level, bone creep may involve the bending of individual trabeculae and parts of the vertebral cortex, particularly near the perimeter of major cavities (or fractures) in porous bone (Novitskaya et al., 2014). Whatever the explanation, bone creep depends on bone mineral density (Ojanen et al., 2015) (Pollintine et al., 2009), to such an extent that it could be a threshold effect (Fondrk et al., 1988), and its acceleration after injury depends on the level of macroscopic disruption to the vertebral cortex and trabeculae (Luo et al., 2012). The protective influence of cement could be to bridge damaged trabeculae and cortex, or to reduce buckling and bending of individual trabeculae. Both of these mechanisms would require close interdigitation of cement into bone (Kruger et al., 2012), and would be enhanced by good adhesion between cement and bone (Helgason et al., 2011). Any subsequent debonding could allow the accelerated creep of the fractured vertebral bone to be re-established. Debonding between a viscoelastic matrix and reinforcing fibres contributes to creep rupture in continuous fibre composites (Nedjar, 2014).

Clinical relevance Results indicate that the mechanical benefits of vertebroplasty on vertebral body shape and load-bearing will continue long after the post-operative radiographs. Injected cement not only helps to restore elastic properties to the vertebra, but also reduces the large creep deformations which affect poorly-mineralised and damaged bones when they are subjected to sustained loading. It is not easy to extrapolate to living people, because bone creep is faster at $37^{\circ} \mathrm{C}$ (Rimnac et al., 1993), and the process may even be reversible in living tissue. Also, the relative magnitude of creep and elastic deformations (Figure 5) will depend on bone density and damage severity, as well as the magnitude and duration of loading. Finally, the ability of vertebroplasty to reduce vertebral deformations in-vivo cannot be assessed reliably if post-operative radiographs are taken in the recumbent position, when spinal loading is relatively low (McKiernan et al., 2003).

Unanswered questions and future research In these experiments, vertebroplasty reduced, but did not entirely reverse, the abnormal load-sharing and bone creep that followed vertebral fracture. It remains to be seen if greater cement volumes, or use of the kyphoplasty technique, can increase the anti-creep effects of cement augmentation. In living patients with osteoporotic vertebral fractures, it would be interesting to monitor progressive changes in vertebral body shape in longitudinal imaging studies, and to compare patients with and without (or before and after) cement augmentation. 


\section{Acknowledgements}

This work was funded by Action Medical Research. Vertebroplasty materials were provided by Stryker and by Orthovita. None of the authors has any conflict of interest, and the sponsors were not involved in study design or the interpretation of data. We thank Clare Costigan for technical support.

\section{Figure Captions}

Figure 1. Vertebral body "creep" increases substantially after damage. These typical creep graphs (showing strain data prior to smoothing) refer to the anterior vertebral body of a female L1 specimen, aged 68 yrs, before and after damage. Reproduced from Luo et al. (Luo et al., 2012) with permission.

Figure 2. (Upper) Each motion segment was secured in two cups of dental plaster and compressed by two low-friction rollers. Three pairs of reflective markers (black dots) indicate the superior and inferior margins of each vertebral body. (Lower) Details of the needle-mounted pressure transducer used to quantify intra-discal compressive stresses. Adapted from Luo et al. (Luo et al., 2012) with permission.

Figure 3. Experimental protocol: see Overview of experiments for details. For stress profilometry, each specimen was positioned in flexion, and then in extension, with the same angles being used after the interventions (fracture, and vertebroplasty). Specimens were positioned in flexion for fracture induction, and were maintained in the neutral position $\left(0^{\circ}\right.$ flexion $)$ for all creep tests.

Figure 4. "Stress profiles" show the intensity of loading, in the vertical and horizontal directions, along the mid-sagittal diameter of a loaded intervertebral disc. Profiles indicate the intradiscal (nucleus) pressure (IDP), and stress peaks (or concentrations) in the posterior and anterior annulus $\left(\mathrm{SP}_{\mathrm{P}}\right.$ and $\mathrm{SP}_{\mathrm{A}}$, respectively).

Figure 5. a) Elastic deformations of the anterior, middle and posterior vertebral body cortex when a motion segment (Fig. 2) is compressed at $1 \mathrm{kN}$. Strains are compared before and after vertebral fracture, and again after vertebroplasty. Error bars indicate the SEM. b) Creep deformations of the same vertebrae during a 1 hour creep test at $1 \mathrm{kN}$. Note that vertebroplasty affects creep strains more than elastic. 
Table 1. Stress profilometry results measured in flexed posture (flex), and in $2^{\circ}$ of extension (ext) to simulate erect standing. Values represent the mean (SD) for 50 discs ( 2 discs from each of 28 specimens, with 6 technical failures). "Post-creep" refers to the final creep test. P values indicate differences between the four stages of the experiment (ANOVA). Post-hoc paired comparisons indicate differences from pre-fracture $\left({ }^{\mathrm{a}} \mathrm{p}<0.05 ;{ }^{\mathrm{b}} \mathrm{p}<0.01 ;{ }^{\mathrm{c}} \mathrm{p}<0.001\right)$ and post-fracture $\left({ }^{\mathrm{A}} \mathrm{p}<\right.$ $\left.0.05 ;{ }^{\mathrm{B}} \mathrm{p}<0.01 ;{ }^{\mathrm{C}} \mathrm{p}<0.001\right)$ values.

\begin{tabular}{ccclcc}
\hline & Pre-fracture & Post-fracture & $\begin{array}{l}\text { Post- } \\
\text { vertebroplasty }\end{array}$ & Post-creep & P \\
\hline $\begin{array}{c}\text { IDP flex } \\
(\mathrm{MPa})\end{array}$ & $0.82(0.46)$ & $0.62(0.37)^{\mathrm{C}}$ & $0.72(0.39)^{\mathrm{B}}$ & $0.68(0.36)^{\mathrm{b}}$ & $<0.001$ \\
$\begin{array}{c}\mathrm{IDP} \text { ext } \\
(\mathrm{MPa})\end{array}$ & $0.80(0.40)$ & $0.47(0.39)^{\mathrm{c}}$ & $0.62(0.39)^{\mathrm{cC}}$ & $0.59(0.36)^{\mathrm{cC}}$ & $<0.001$ \\
$\begin{array}{c}\mathrm{SP}_{\mathrm{A}} \text { flex } \\
(\mathrm{MPa})\end{array}$ & $1.49(1.41)$ & $1.02(0.94)^{\mathrm{b}}$ & $1.09(0.98)$ & $1.24(1.17)$ & 0.003 \\
$\begin{array}{c}\mathrm{SP}_{\mathrm{A}} \text { ext } \\
(\mathrm{MPa})\end{array}$ & $0.63(0.64)$ & $0.63(0.59)$ & $0.67(0.58)$ & $0.58(0.51)$ & 0.406 \\
$\begin{array}{c}\mathrm{SP} \text { flex } \\
(\mathrm{MPa})\end{array}$ & $0.38(0.61)$ & $0.81(0.83)^{\mathrm{b}}$ & $0.42(0.51)^{\mathrm{B}}$ & $0.40(0.51)^{\mathrm{B}}$ & $<0.001$ \\
$\begin{array}{c}\mathrm{SP} P_{\mathrm{P}} \text { ext } \\
(\mathrm{MPa})\end{array}$ & $0.76(0.83)$ & $1.42(1.05)^{\mathrm{C}}$ & $0.94(0.71)^{\mathrm{C}}$ & $0.95(0.72)^{\mathrm{C}}$ & $<0.001$ \\
\hline
\end{tabular}


Table 2. Elastic and creep strains recorded in the anterior, middle, and posterior cortex of vertebrae which were adjacent to a fractured endplate, and for which complete data sets were available. Values refer to the mean (STD), and units are micro-strains, where 10,000 micro-strains represents $1 \%$ compressive deformation. Significant differences from pre-fracture $\left({ }^{\mathrm{a}} \mathrm{p}<0.05 ;{ }^{\mathrm{b}} \mathrm{p}<0.01 ;{ }^{\mathrm{c}} \mathrm{p}<\right.$ $0.001)$ and post-fracture $\left({ }^{\mathrm{A}} \mathrm{p}<0.05 ;{ }^{\mathrm{B}} \mathrm{p}<0.01 ;{ }^{\mathrm{C}} \mathrm{p}<0.001\right)$ were indicated.

\begin{tabular}{llll}
\hline & \multicolumn{2}{c}{ Strain in the vertebral body cortex $(\mu$ strain $)$} \\
\cline { 2 - 4 } & Anterior $(\mathrm{n}=26)$ & Middle $(\mathrm{n}=25)$ & Posterior $(\mathrm{n}=29)$ \\
\hline $\begin{array}{l}\text { Pre-fracture } \\
\text { Elastic }\end{array}$ & $10,233(15,798)$ & $3,095(7,464)$ & $4,524(5,122)$ \\
Creep & $4,513(4,766)$ & $885(5,170)$ & $2,087(4,591)$ \\
Post-fracture & & & \\
Elastic & $80,723(90,105)^{\mathrm{b}}$ & $38,638(45,512)^{\mathrm{b}}$ & $16,164(26,253)^{\mathrm{a}}$ \\
Creep & $54,107(54,845)^{\mathrm{c}}$ & $34,378(40,762)^{\mathrm{c}}$ & $19,658(43,465)$ \\
Post-vertebroplasty & & & \\
Elastic & $63,414(77,567)^{\mathrm{b}}$ & $28,673(35,158)^{\mathrm{b}}$ & $21,881(41,412)$ \\
Creep & $20,915(27,736)^{\mathrm{aB}}$ & $11,690(11,924)^{\mathrm{bA}}$ & $8,194(15,965)$ \\
\hline
\end{tabular}




\section{References}

Adams MA. 1995. Mechanical testing of the spine. An appraisal of methodology, results, and conclusions. Spine (Phila Pa 1976) 20:2151-2156.

Adams MA, Dolan P, Hutton WC. 1986. The stages of disc degeneration as revealed by discograms. J Bone Joint Surg Br 68:36-41.

Adams MA, Hutton WC. 1980. The effect of posture on the role of the apophysial joints in resisting intervertebral compressive forces. J Bone Joint Surg Br 62:358-362.

Adams MA, McNally DS, Dolan P. 1996. 'Stress' distributions inside intervertebral discs. The effects of age and degeneration. J Bone Joint Surg Br 78:965-972.

Adams MA, Pollintine P, Tobias JH, Wakley GK, Dolan P. 2006. Intervertebral disc degeneration can predispose to anterior vertebral fractures in the thoracolumbar spine. J Bone Miner Res 21:1409-1416.

Bass EC, Duncan NA, Hariharan JS, Dusick J, Bueff HU, Lotz JC. 1997. Frozen storage affects the compressive creep behavior of the porcine intervertebral disc. Spine 22:2867-2876.

Bayraktar HH, Morgan EF, Niebur GL, Morris GE, Wong EK, Keaveny TM. 2004. Comparison of the elastic and yield properties of human femoral trabecular and cortical bone tissue. $\mathrm{J}$ Biomech 37:27-35.

Belkoff SM, Maroney M, Fenton DC, Mathis JM. 1999. An in vitro biomechanical evaluation of bone cements used in percutaneous vertebroplasty. Bone 25:23S-26S.

Briggs AM, Perilli E, Parkinson IH, Kantor S, Wrigley TV, Fazzalari NL, Wark JD. 2012. Measurement of subregional vertebral bone mineral density in vitro using lateral projection dual-energy X-ray absorptiometry: validation with peripheral quantitative computed tomography. J Bone Miner Metab 30:222-231.

Brinckmann P, Frobin W, Hierholzer E, Horst M. 1983. Deformation of the vertebral end-plate under axial loading of the spine. Spine 8:851-856.

Buchbinder R, Osborne RH, Ebeling PR, Wark JD, Mitchell P, Wriedt C, Graves S, Staples MP, Murphy B. 2009. A randomized trial of vertebroplasty for painful osteoporotic vertebral fractures. N Engl J Med 361:557-568.

Burger H, Van Daele PL, Grashuis K, Hofman A, Grobbee DE, Schutte HE, Birkenhager JC, Pols HA. 1997. Vertebral deformities and functional impairment in men and women. J Bone Miner Res 12:152-157.

Chu JY, Skrzypiec D, Pollintine P, Adams MA. 2008. Can compressive stress be measured experimentally within the annulus fibrosus of degenerated intervertebral discs? Proc Inst Mech Eng [H] 222:161-170.

Currey JD. 1965. Anelasticity in Bone and Echinoderm Skeletons. J Exp Biol 43:279-292.

Dhillon N, Bass EC, Lotz JC. 2001. Effect of frozen storage on the creep behavior of human intervertebral discs. Spine 26:883-888.

Dolan P, Earley M, Adams MA. 1994. Bending and compressive stresses acting on the lumbar spine during lifting activities. J Biomech 27:1237-1248.

Dolan P, Luo J, Pollintine P, Landham PR, Stefanakis M, Adams MA. 2013. Intervertebral disc decompression following endplate damage: implications for disc degeneration depend on spinal level and age. Spine (Phila Pa 1976) 38:1473-1481.

Eberhardsteiner L, Hellmich C, Scheiner S. 2014. Layered water in crystal interfaces as source for bone viscoelasticity: arguments from a multiscale approach. Comput Methods Biomech Biomed Engin 17:48-63.

Ettinger B, Pressman A, Sklarin P, Bauer DC, Cauley JA, Cummings SR. 1998. Associations between low levels of serum estradiol, bone density, and fractures among elderly women: the study of osteoporotic fractures. J Clin Endocrinol Metab 83:2239-2243. 
Fondrk M, Bahniuk E, Davy DT, Michaels C. 1988. Some viscoplastic characteristics of bovine and human cortical bone.[see comment]. Journal of Biomechanics 21:623-630.

Francis RM, Aspray TJ, Hide G, Sutcliffe AM, Wilkinson P. 2008. Back pain in osteoporotic vertebral fractures. Osteoporos Int 19:895-903.

Garfin SR, Yuan HA, Reiley MA. 2001. New technologies in spine: kyphoplasty and vertebroplasty for the treatment of painful osteoporotic compression fractures. Spine 26:1511-1515.

Green TP, Allvey JC, Adams MA. 1994. Spondylolysis. Bending of the inferior articular processes of lumbar vertebrae during simulated spinal movements. Spine 19:2683-2691.

Helgason B, Stirnimann P, Widmer R, Ferguson SJ. 2011. Experimental and computational models to investigate the effect of adhesion on the mechanical properties of bone-cement composites. J Biomed Mater Res B Appl Biomater 99:191-198.

Hulme PA, Boyd SK, Heini PF, Ferguson SJ. 2009. Differences in endplate deformation of the adjacent and augmented vertebra following cement augmentation. Eur Spine J 18:614-623.

Ismail AA, Cooper C, Felsenberg D, Varlow J, Kanis JA, Silman AJ, O'Neill TW. 1999. Number and type of vertebral deformities: epidemiological characteristics and relation to back pain and height loss. European Vertebral Osteoporosis Study Group. Osteoporos Int 9:206-213.

Ismail AA, O'Neill TW, Cooper C, Silman AJ. 2000. Risk factors for vertebral deformities in men: relationship to number of vertebral deformities. European Vertebral Osteoporosis Study Group. J Bone Miner Res 15:278-283.

Jiang G, Luo J, Pollintine P, Dolan P, Adams MA, Eastell R. 2010. Vertebral fractures in the elderly may not always be "osteoporotic". Bone 47:111-116.

Kallmes DF, Comstock BA, Heagerty PJ, Turner JA, Wilson DJ, Diamond TH, Edwards R, Gray LA, Stout L, Owen S, Hollingworth W, Ghdoke B, Annesley-Williams DJ, Ralston SH, Jarvik JG. 2009. A randomized trial of vertebroplasty for osteoporotic spinal fractures. N Engl J Med 361:569-579.

Kruger A, Oberkircher L, Kratz M, Baroud G, Becker S, Ruchholtz S. 2012. Cement interdigitation and bone-cement interface after augmenting fractured vertebrae: A cadaveric study. International journal of spine surgery 6:115-123.

Landham PR, Baker-Rand HL, Gilbert SJ, Pollintine P, Annesley-Williams DJ, Adams MA, Dolan P. 2015a. Is kyphoplasty better than vertebroplasty at restoring form and function after severe vertebral wedge fractures? Spine J 15:721-732.

Landham PR, Gilbert SJ, Baker-Rand HLA, Pollintine P, Robson-Brown KA, Adams MA, Dolan P. 2015b. Pathogenesis of vertebral anterior wedge deformity. A two-stage process? Spine 40 (12): 902-8.

Luo J, Bertram W, Sangar D, Adams MA, Annesley-Williams DJ, Dolan P. 2010. Is kyphoplasty better than vertebroplasty in restoring normal mechanical function to an injured spine? Bone 46:1050-1057.

Luo J, Daines L, Charalambous A, Adams MA, Annesley-Williams DJ, Dolan P. 2009. Vertebroplasty: only small cement volumes are required to normalize stress distributions on the vertebral bodies. Spine (Phila Pa 1976) 34:2865-2873.

Luo J, Pollintine P, Gomm E, Dolan P, Adams MA. 2012. Vertebral deformity arising from an accelerated "creep" mechanism. Eur Spine J 21:1684-1691.

Luo J, Skrzypiec DM, Pollintine P, Adams MA, Annesley-Williams DJ, Dolan P. 2007. Mechanical efficacy of vertebroplasty: Influence of cement type, BMD, fracture severity, and disc degeneration. Bone 40:1110-1119.

McKiernan F, Jensen R, Faciszewski T. 2003. The dynamic mobility of vertebral compression fractures. J Bone Miner Res 18:24-29.

McMillan DW, Garbutt G, Adams MA. 1996. Effect of sustained loading on the water content of intervertebral discs: implications for disc metabolism. Ann Rheum Dis 55:880-887. 
McNally DS, Adams MA. 1992. Internal intervertebral disc mechanics as revealed by stress profilometry. Spine 17:66-73.

McNally DS, Adams MA, Goodship AE. 1992. Development and validation of a new transducer for intradiscal pressure measurement. J Biomed Eng 14:495-498.

Miyakoshi N, Hongo M, Kobayashi T, Abe T, Abe E, Shimada Y. 2015. Improvement of spinal alignment and quality of life after corrective surgery for spinal kyphosis in patients with osteoporosis: a comparative study with non-operated patients. Osteoporos Int.

Nedjar B. 2014. Modeling long-term creep rupture by debonding in unidirectional fibre-reinforced composites. Int J Solids Struct 51:1962-1969.

Novitskaya E, Zin C, Chang N, Cory E, Chen P, D'Lima D, Sah RL, McKittrick J. 2014. Creep of trabecular bone from the human proximal tibia. Materials science \& engineering $\mathrm{C}$, Materials for biological applications 40:219-227.

Ojanen X, Isaksson H, Toyras J, Turunen MJ, Malo MK, Halvari A, Jurvelin JS. 2015. Relationships between tissue composition and viscoelastic properties in human trabecular bone. J Biomech 48:269-275.

Pollintine P, Dolan P, Tobias JH, Adams MA. 2004a. Intervertebral disc degeneration can lead to "stress-shielding" of the anterior vertebral body: a cause of osteoporotic vertebral fracture? Spine 29:774-782.

Pollintine P, Luo J, Offa-Jones B, Dolan P, Adams MA. 2009. Bone creep can cause progressive vertebral deformity. Bone 45:466-472.

Pollintine P, Przybyla AS, Dolan P, Adams MA. 2004b. Neural arch load-bearing in old and degenerated spines. J Biomech 37:197-204.

Rimnac CM, Petko AA, Santner TJ, Wright TM. 1993. The effect of temperature, stress and microstructure on the creep of compact bovine bone. J Biomech 26:219-228.

Rohlmann A, Consmüller T, Dreischarf M, Bashkuev M, Disch A, Pries E, Duda G, Schmidt H. 2014. Measurement of the number of lumbar spinal movements in the sagittal plane in a 24 hour period. European Spine Journal 23:2375-2384.

Seref-Ferlengez Z, Basta-Pljakic J, Kennedy OD, Philemon CJ, Schaffler MB. 2014. Structural and mechanical repair of diffuse damage in cortical bone in vivo. J Bone Miner Res 29:25372544.

Singhal A, Stock SR, Almer JD, Dunand DC. 2014. Effect of cyclic loading on the nanoscale deformation of hydroxyapatite and collagen fibrils in bovine bone. Biomech Model Mechanobiol 13:615-626.

Stefanakis M, Luo J, Pollintine P, Dolan P, Adams MA. 2014. ISSLS Prize Winner: Mechanical Influences in Progressive Intervertebral Disc Degeneration. Spine (Phila Pa 1976) 39:136572.

Tower RJ, Campbell GM, Muller M, Gluer CC, Tiwari S. 2015. Utilizing time-lapse microCTcorrelated bisphosphonate binding kinetics and soft tissue-derived input functions to differentiate site-specific changes in bone metabolism in vivo. Bone 74:171-181.

Yamamoto E, Paul Crawford R, Chan DD, Keaveny TM. 2006. Development of residual strains in human vertebral trabecular bone after prolonged static and cyclic loading at low load levels. J Biomech 39:1812-1818.

Zilch H, Rohlmann A, Bergmann G, Kolbel R. 1980. Material properties of femoral cancellous bone in axial loading. Part II: Time dependent properties. Arch Orthop Trauma Surg 97:257-262.

Zioupos P, Hansen U, Currey JD. 2008. Microcracking damage and the fracture process in relation to strain rate in human cortical bone tensile failure. J Biomech 41:2932-2939. 



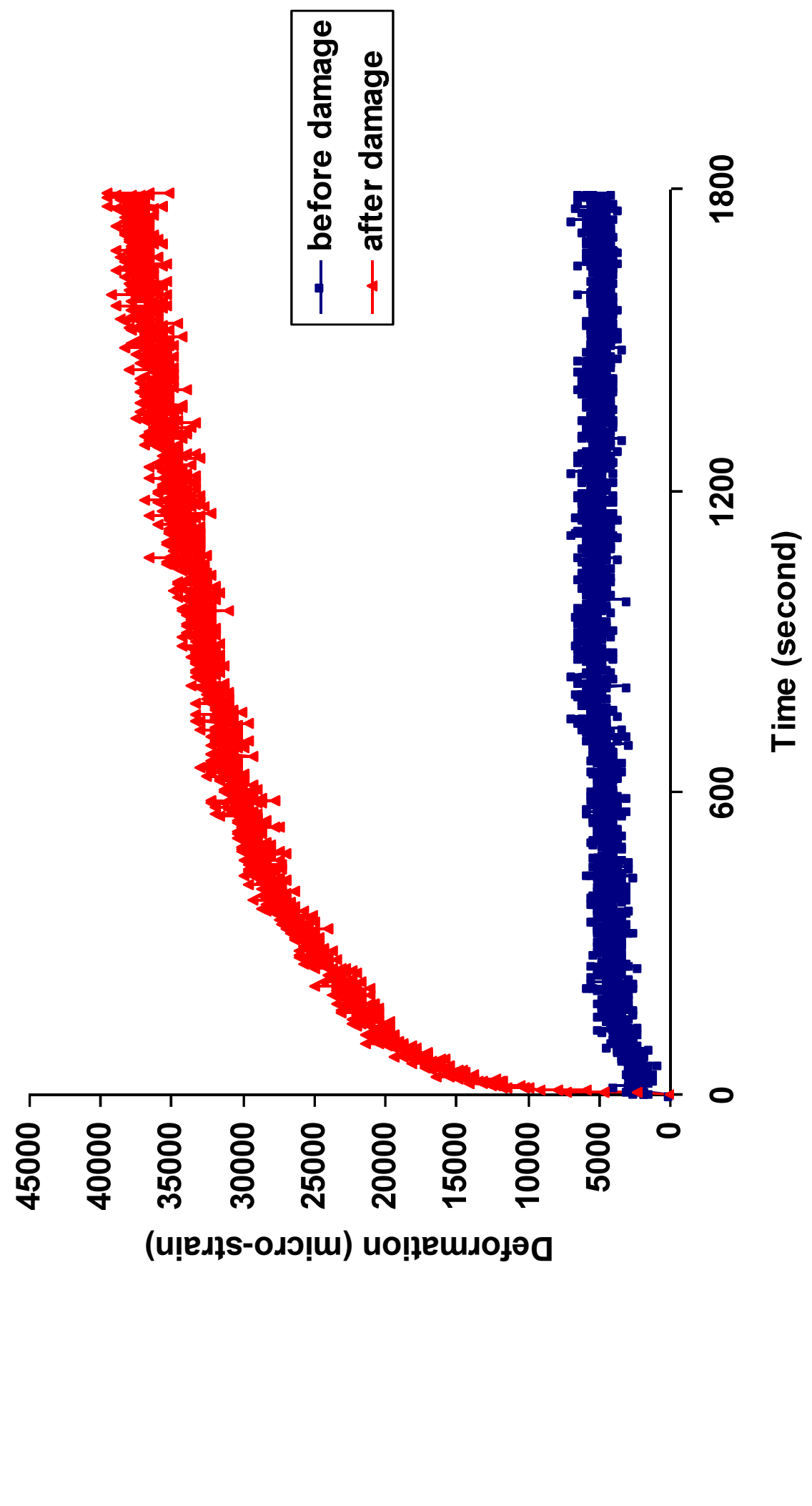




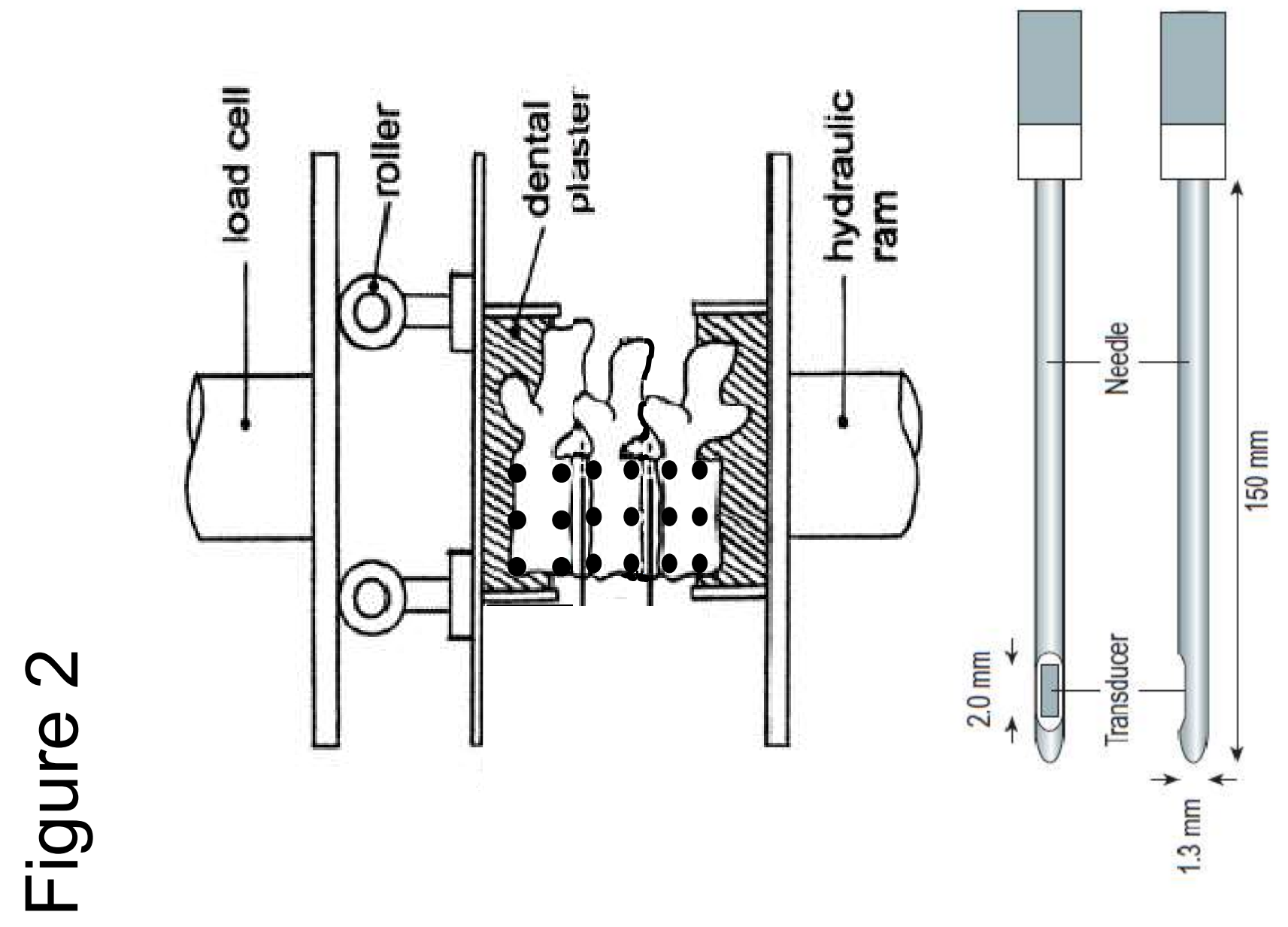




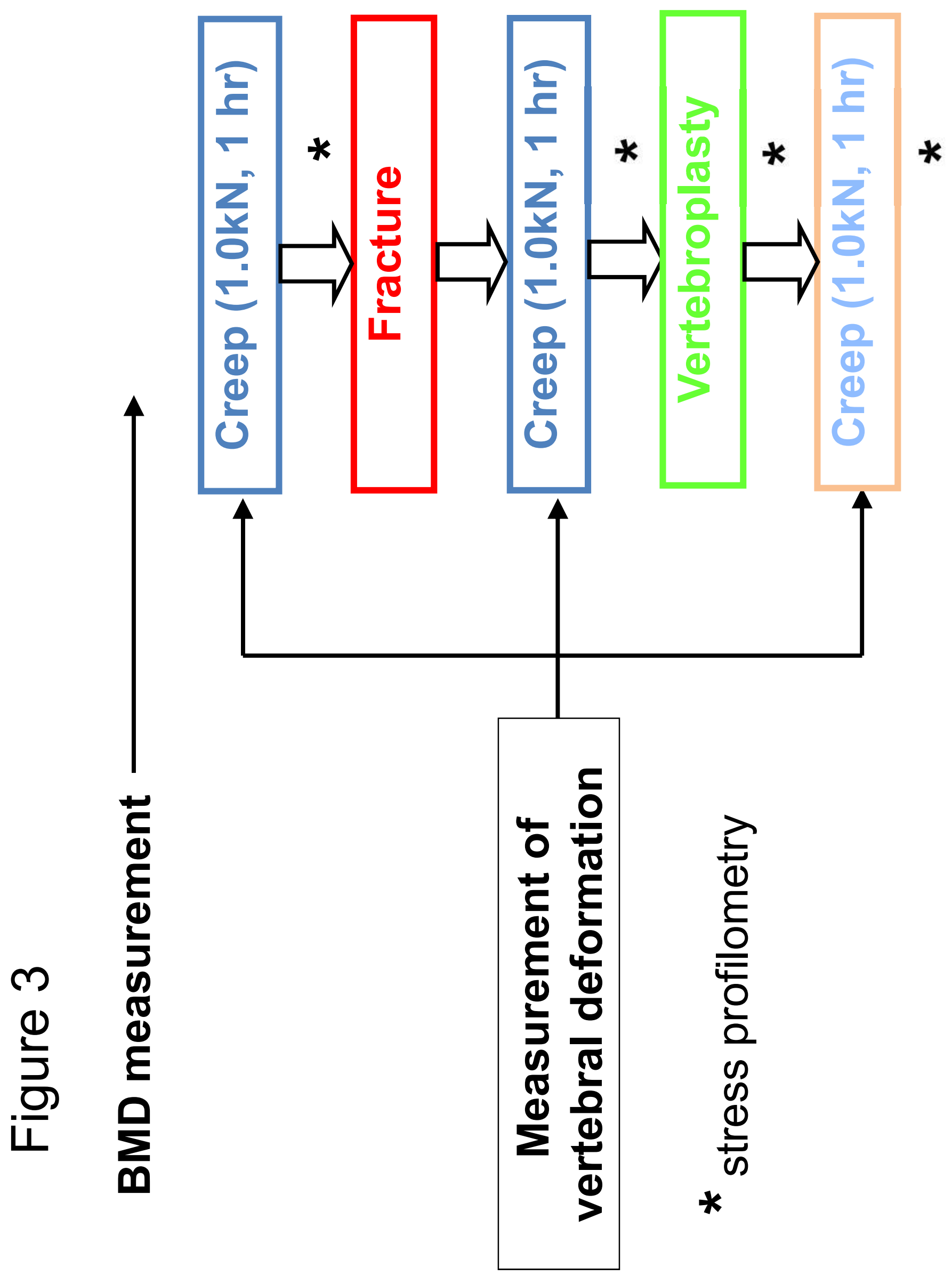




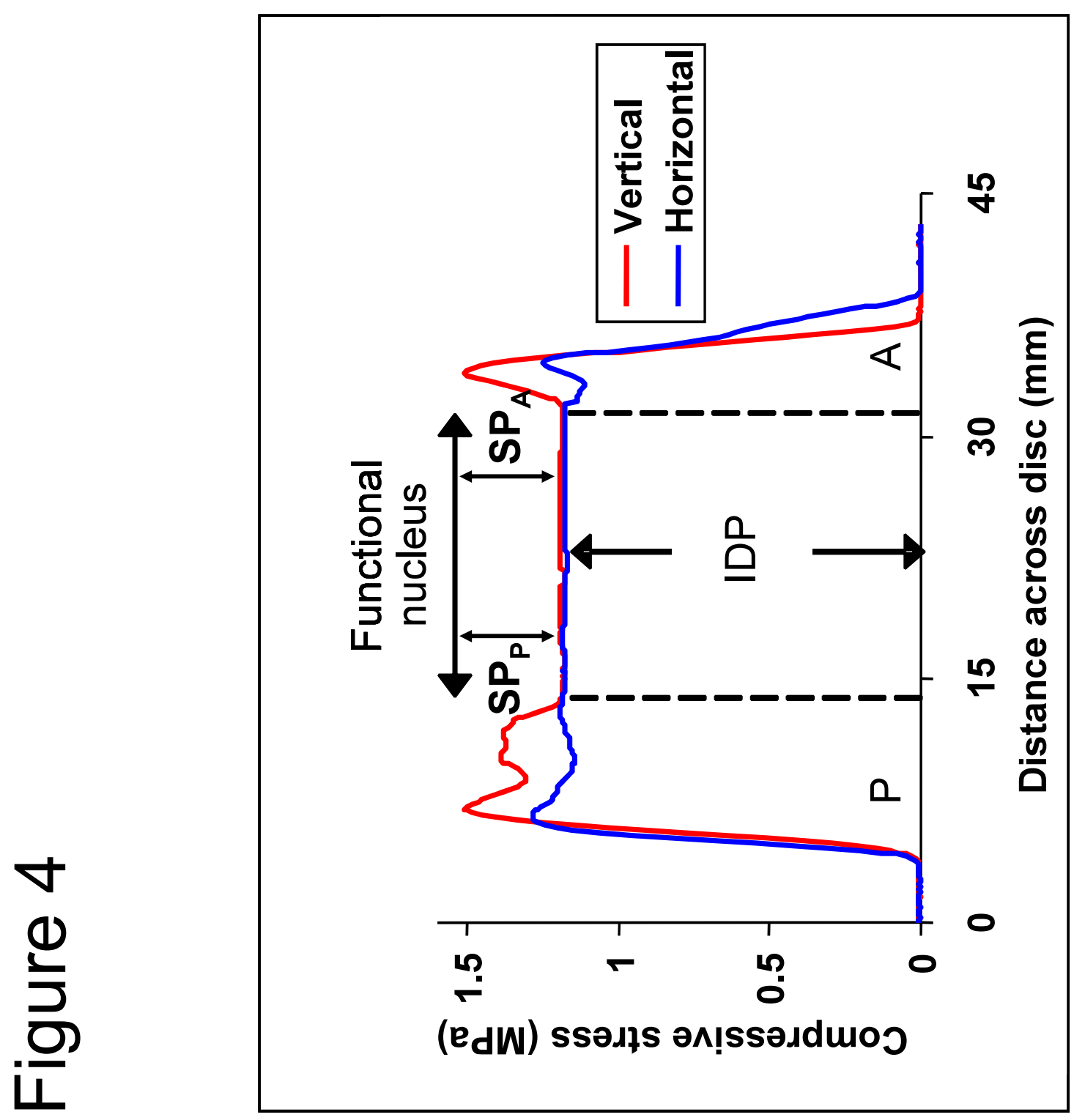


กั

옥

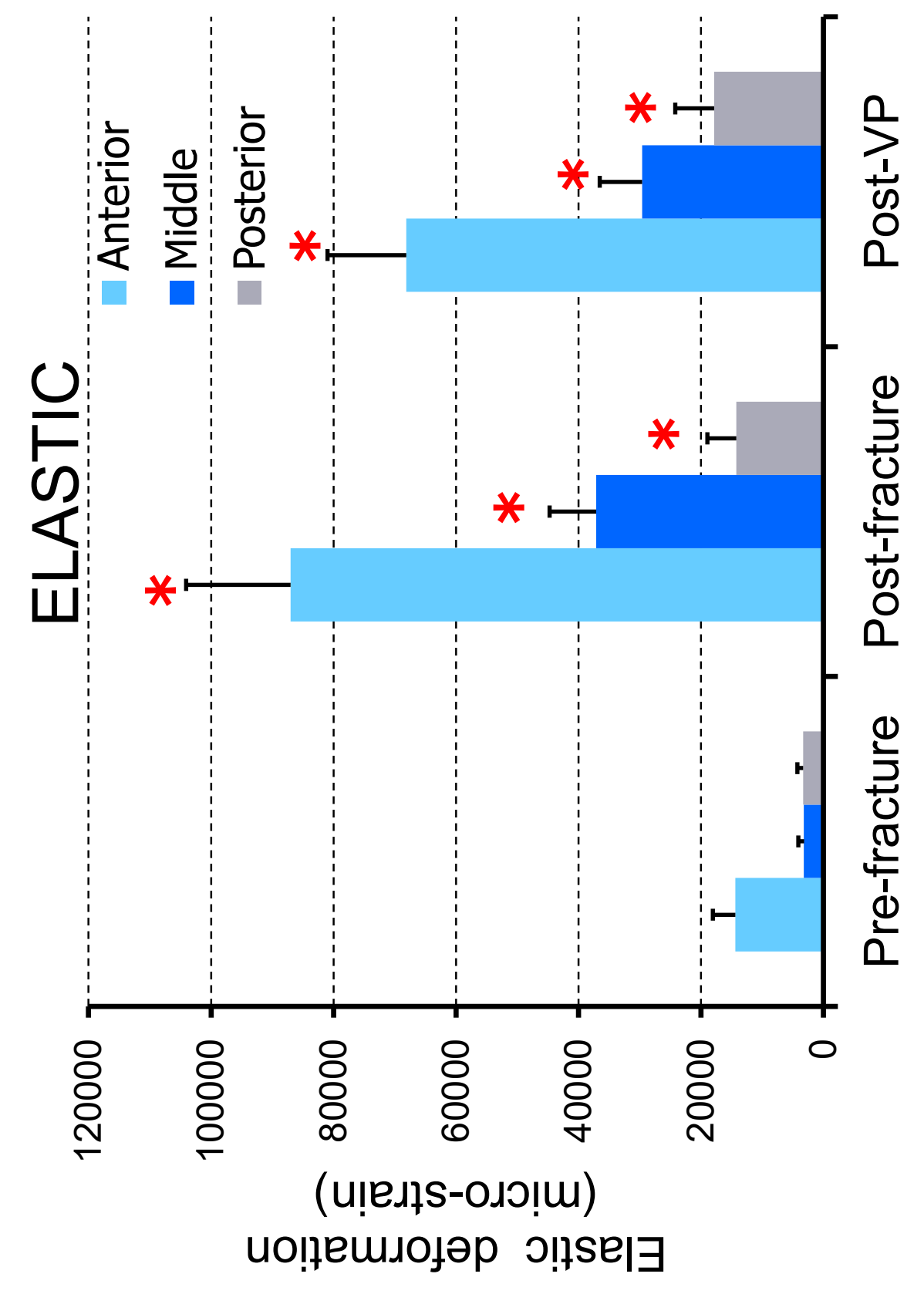




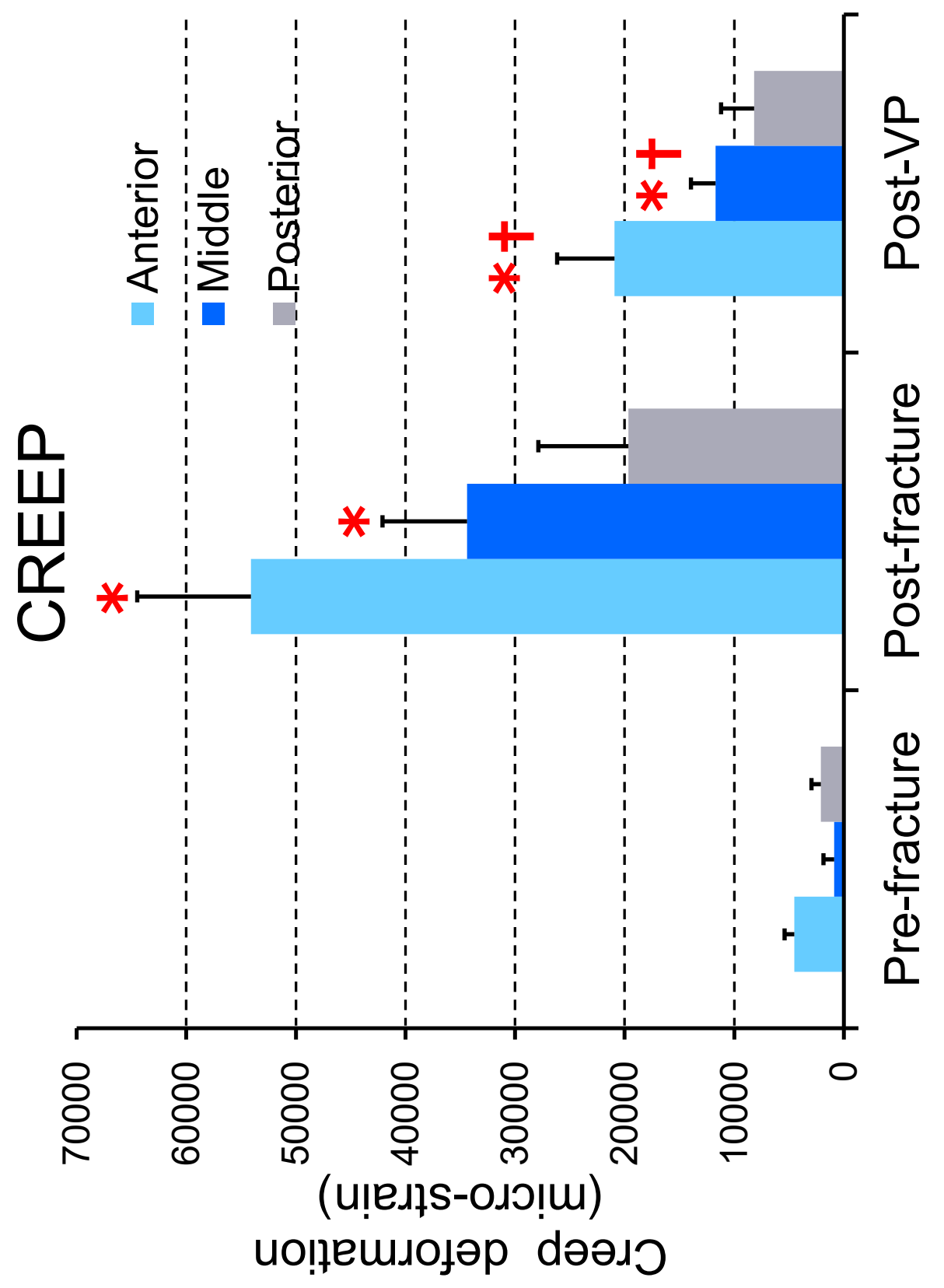

은 